\title{
26
}

\section{Information Technology resources for education in developing countries}

\author{
Marsha R. Williams \\ CDP Professor of Computer Science
}

Director of Project MISET (Minorities in Science, Engineering \& Technology)

Department of Computer Science, Tennessee State University 3500 John A. Merritt Blvd. McCord Hall, Room 5

P.O. Box 9604

Nashville, TN 37209-1561, USA

Tele + 615963-7039 or 615963 5852; Fax + 6159635099

E-mail:WILL002@ACAD.TNSTATE.EDU

\begin{abstract}
Information Technology (IT) resources include not only equipment, particularly computers, but also software and experts as well as students, teachers and parents. Resources are provided by government, industry, education, associations and collaborations. Developing countries, which are often rich in people, land and natural resources, are, in many cases, poor in even the traditional educational resources (teachers, schools, desks and books). They are especially poor in IT resources. In this paper, IT resources for education in developing countries are reported from available statistical data and from related literature. IT resources have the potential for making education accessible and enhanced for many, even over great distances - which is a critical need in many developing countries. A hierarchy of IT resources is described, which, if considered as a whole, and applied appropriately and respectfully, could play a key role in building the capacity of a developing country for improving not only education but also government, business and the quality of life for all.
\end{abstract}

Capacity Building for IT in Education in Developing Countries

G. Marshall \& M. Ruohonen (Eds.)

(C) 1998 IFIP. Published by Chapman \& Hall 


\section{Keywords}

Informatics, resources, developing countries, elementary education, secondary education, higher education, vocational education

\section{INTRODUCTION}

Information Technology (IT) is a means of communication and telecommunication over large distances, involving a combination of computers, networks, satellites, telephones, radio, television and other electronics (Stover, 1984). IT resources involve not only equipment (hardware) but also software (programs), people, education, government and association/collaboration resources. The consideration of the many resources required for the application of IT to education involves many disciplines related to computers in the handling, processing, management, automation and communication of information in the broader cultural and economic context of a society. The discipline, which is called informatics, is a new and modern form of communication (Stover, 1984)

The commonly-referenced terms, developed countries and developing countries, were not found to have standard international definitions and there will be exceptions to the descriptions used herein. Developed countries (New Encyclopedia Brittanica, 1980) are generally high-income, industrialized countries with high per capita gross domestic product (GDP - the value of goods and services produced within a nation in a year; the gross national product (GNP) is the GDP, plus income earned abroad, minus income earned by foreigners from domestic production.), high literacy rates and low rates of population growth. Countries such as the United States, Japan and the United Kingdom are considered as developed countries.

Developing countries (New Encyclopedia Brittanica, 1980), underdeveloped or less-developed, 'Third World' countries are generally low-income, agricultural countries with low per capita GDP, low literacy rates and high rates of population growth. At the top (in terms of development) of the group of less-developed countries are the newly-industrializing economies (OECD, 1992) or advanced developing countries, whose economies have experienced rapid industrialization, including Brazil, Hong Kong, Mexico and Singapore. At the bottom of the group of developing countries is a group called least-developed, or undeveloped, countries with no significant economic growth, very low per capita GDP and low literacy rates.

Much of the data on IT resources for education in developing countries reported here will use the format of the UNESCO (1997) grouping of countries into developed countries and developing countries. UNESCO further subdivides the developing countries into six sub-groupings (Sub-Saharan Africa, Arab States, Latin America and the Caribbean, Eastern Asia and Oceania, Southern Asia and the Least Developed Countries). The UNESCO groupings will be used in this paper's tables with selected data from some of the UNESCO tables (1997), along with data and calculations from a number of other sources. Although data on the status of IT in developing countries is limited and not the latest, it nevertheless shows the big picture of IT resources in a few developing countries from each of the major world sub-groupings in comparison to two major developed countries. 
Key resources for the use of IT in education are equipment resources such as the computer, television and radio. Table 1 shows the radios, televisions, phones and computers per 1,000 inhabitants in selected developing and developed countries (for comparison). The criteria for selection were simply the availability of pertinent data, particularly on computers in these countries.

According to The Computer Industry Almanac estimates (1994), there were approximately 173 million computers in use worldwide by the end of 1993, with nearly $43 \%$, or 74 million computers, in use in the USA alone. Another $40 \%$ of the world's computers were used in 17 other large industrialized, developed countries such as Japan, Germany, UK and France, which accounted for just over four-fifths of the world's computers. This left less than one-fifth, or approximately 29.4 million computers, in use in the nearly 200 other countries of the world, including less-developed countries (more than three-quarters of the world's population). If all the 29.4 million computers were in developing countries (and they are not), there were roughly 7 computers per 1000 inhabitants in lessdeveloped countries at the end of 1993. As is shown in Table 1, the computers for the selected developing countries are near this rough estimate. Hong Kong, which is one of the newly industrializing economies, shows a much higher number of computers.

Radios, televisions and telephones are much more plentiful than computers in the selected developing countries but are still far less available in the developing countries than in the developed countries. Table 1 also gives some indication of the amount of educational programming on TV and on radio in a few countries.

Television broadcasting in developing countries has presented a number of problems, such as technician training on appropriate technology, expensive, advanced broadcasting equipment and lack of frequency/line standardization for sharing programs. As seen in Table 1 there are many more radios in developing countries than televisions, which vastly outnumber computers, at least for the selected countries.

Though cost-prohibitive for most developing countries, satellite technology has offered a means of delivering distance education to remote locations in Mexico, a number of Southeast Asian nations (Sussman and Lent, 1991) and India (Stover, 1984). Volunteers in Technical Assistance (VITA, www.vita.org on the World Wide Web), a private organization that provides technical assistance and information to developing countries, has developed a global communications system (VITAcomm) which consists of VITASAT (low-earth-orbiting system, LEO, for messages and files), VITAPAC (independent terrestrial digital radio systems for low-cost radio communication with computers) and VITANET (electronic message delivery system, mailer and bulletin board, using existing telephone networks). VITAcomm technologies can be used anywhere in the world, even if telephone and electricity resources are not available, which can be the norm in rural areas of a developing country, though the use for education is presently unknown. 
Table 1 IT equipment resources

\begin{tabular}{|c|c|c|c|c|c|c|}
\hline & $\begin{array}{l}\text { Radio }^{\text {ac }} \\
\text { per } 1000\end{array}$ & $\begin{array}{l}\text { TV per } \\
1000\end{array}$ & $\begin{array}{l}\text { Phones }^{\mathrm{b}} \\
\text { per } 1000\end{array}$ & $\begin{array}{l}\text { Computers } \\
{ }^{\mathrm{b}} \text { per } 1000\end{array}$ & $\begin{array}{l}\text { Education } \\
\text { al } \\
\text { program } \\
\text { hours } \\
\text { Radio }\end{array}$ & TV \\
\hline \multicolumn{7}{|l|}{ Developing } \\
\hline Countries & & 104 & & & & \\
\hline Sub-Sahara & 152 & 28 & & & & \\
\hline Zimbabwe & 71 & 27 & $12^{\mathrm{c}}$ & \multicolumn{3}{|c|}{ Africa } \\
\hline Arab States & 251 & 104 & & & & \\
\hline Saudi & 217 & 255 & 160 & 24 & 2.0 & \\
\hline \multicolumn{7}{|l|}{ Arabia } \\
\hline Latin & 354 & 171 & & & & \\
\hline \multicolumn{7}{|l|}{ America } \\
\hline Mexico & 233 & 163 & $91^{c}$ & 17 & & \\
\hline Eastern & 197 & 156 & & & & \\
\hline \multicolumn{7}{|l|}{ Asia } \\
\hline \multicolumn{7}{|l|}{ Oceania } \\
\hline China & 172 & 189 & 12 & 9 & & \\
\hline Hong Kong & $588^{d}$ & 291 & 570 & 101 & & \\
\hline Southern & 88 & 35 & & & & \\
\hline \multicolumn{7}{|l|}{ Asia } \\
\hline Pakistan & 402 & 77 & 19 & $13^{c}$ & 6.6 & 7.0 \\
\hline Least & 98 & 10 & & & & \\
\hline \multicolumn{7}{|l|}{ Developed } \\
\hline \multicolumn{7}{|l|}{ Countries } \\
\hline Kiribati & 161 & 192 & $23^{c}$ & & 88.7 & \\
\hline \multicolumn{7}{|l|}{ Developed } \\
\hline \multicolumn{7}{|l|}{ Countries } \\
\hline USA & 2000 & 817 & 965 & 287 & & \\
\hline UK & 1111 & 439 & 615 & 162 & & \\
\hline World & 357 & 195 & 155 & 31 & & \\
\hline
\end{tabular}

${ }^{a}$ UNESCO Statistical Yearbook, $1996 \quad{ }^{\mathrm{b}}$ Computer Industry Almanac, 1994

${ }^{c}$ World Almanac (individual nation), 1997 d Brittanica Book of the Year, 1997 
An International Connectivity Table (Version 15, June 15, 1996) is available on the World Wide Web that shows the network connections of nations around the world (ftp.cs.wisc.edu). From that table, the selected developing countries in this paper were found to have 1-3 network connections. Most of the cited developing countries showed all three connections - International IP Internet links, UUCP sites and FIDONET sites for e-mail only, with some sites not being widespread. Developing countries with less than all three connections were Hong Kong (IP, FIDONET), Pakistan (IP, UUCP), Saudi Arabia (IP) and Kiribati (minimal UUCP). A related connectivity map of Africa showed about one-third of Africa with no network connectivity at all and about another third with e-mail only as of November 1995. E-mail connections in Zimbabwe, for example, are provided through the nationwide FIDONET and the University of Zimbabwe's Zimbix network with Internet connection through Rhodes University in South Africa (Buxton, 1995). CD-ROM is used to search databases, and several schools in Harare communicate about the environment and climate with other schools around the world in the Global Laboratory program. One Harare school participates in the Global Student Village program, receiving meteorology satellite signals and connecting via e-mail to USA Global Student Village schools.

In addition to the equipment, or hardware, requirements for the use of IT in education, there must also be software, or programs and applications, to direct the hardware in producing information that is educationally useful. Such software resources can range from simple games, word processing, programming and drilland-practice to sophisticated programming, computer-assisted instruction (CAI), computer-managed instruction (CMI), computer-aided learning (CAL) and simulations in support of education. For example, the Korean Educational Development Institute developed a collection of CAI software for improving the teaching/learning process in the late eighties (Hebenstreit, et. al., 1992). Various computer media - interactive videodisc players and the newer compact disk (CDROM) drives in microcomputers - are being employed in education, but no statistical data specific to their use in developing countries was found.

\section{IT GOVERNMENT, PEOPLE AND EDUCATION RESOURCES}

A group of nine small countries, most with populations less than or near 5 million, were recently reported as major IT producers or sophisticated users (Dedrick, Goodman and Kraemer, 1995), including two developing countries that are newly industrializing economies - Hong Kong and Singapore. The other countries were Denmark, Finland, Ireland, Israel, New Zealand, Norway and Sweden. The report looked at the factors that determine a small country's IT success, or lack thereof. Environmental factors included a minimum development level (more than a few thousand GDP per capita), a good basic educational system and high literacy rates or specialized skills. In all the small countries there are communities well-connected to the international IT community (Internet, conferences, journals) with advanced telecommunications infrastructures. The report noted that an open government policy towards foreign trade and investment is a key factor, as well as government promotion of IT production and use. 
While very few developing countries fit this profile, the report suggests the critical resources needed to begin to approach such a level of IT achievement, even for a small country. Though IT data and its use in education are not available for many developing countries, Table 2 is a compilation of data that indicates the status of such IT resources as government spending in areas related to IT, and education and literacy levels. The countries cited are the same ones that appear in Table 1 for continuity and consistency.

For the developing countries R\&D expenditure as a percentage of GNP (1997) is low in comparison to that of developed countries, as is the GDP per capita, with the exception of the newly industrializing economy of Hong Kong, whose GDP is comparable to that of the United States and higher than that of the United Kingdom! 1990 IT spending estimates in billions of 1990 US\$, as reported by the Organisation for Economic Cooperation and Development (OECD) (OECD, 1992), are available for only a few developing countries, where the estimates are all low, compared to the cited developed countries.

Using data from the International Data Corporation (1990) the 1990 world IT spending on products and services is $\$ 305$ billion (US\$). The growth rate of the world IT market (1989-90) is estimated to be $12 \%$, with software accounting for the majority of this growth (17\%). The IT spending breakdown (1989) was 60$70 \%$ for hardware ( $90 \%$ for China), $20-30 \%$ for software, $1-5 \%$ for data

communications and $5-10 \%$ for data services. As expected, hardware is a major investment for IT users. Only six developed countries accounted for $80 \%$ of the world IT spending - USA, Japan, Germany, France, UK and Italy. Ten developing countries (newly industrializing economies) accounted for $5 \%$ of world IT spending in 1989.

Table 2 shows that public education spending (1994 US\$) per capita in developing countries (UNESCO, 1997), from which would likely come IT educational spending, is very low for least-developed countries, Asia, Oceania and Africa. As expected, per capita education spending in developing countries is far less than in the developed countries. Literacy rates, as indicated by the percent of literate of persons over age 15 as shown in Table 2, are low for Sub-Sahara Africa, the Arab States, Southern Asia and the least-developed countries. It is the literate population that would be potential first trainees in the use of IT and could then assist in bringing literacy to the rest of the population with the help of IT!

Katz (1988) reported politics (growth of government) as the decisive variable in the transition of developing countries to information societies. For example, in a developing country the government may operate the existing communication industries and impose tariffs to protect the industries from new information technologies. Earlier researchers showed that the growth of information occupations and the diffusion (adaptation and use in society) of IT in developed countries are mainly determined by the growth in markets/economy (production of goods and services), influenced by politics. 
Table 2 IT government/people/education resources

\begin{tabular}{lllll}
\hline GDP per & $\begin{array}{l}\text { Literacy \% } \\
\text { over age } \\
\text { Capita }^{\mathrm{d}}\end{array}$ & $\begin{array}{l}\text { R\&D } \\
\text { expenditures } \\
\text { as \% GDP }\end{array}$ & $\begin{array}{l}\text { Higher Ed } \\
\text { R\&D } \\
\text { personnel }\end{array}$ & $\begin{array}{l}\text { Public } \\
\text { education } \\
\text { spending } \\
\text { per capita }\end{array}$ \\
\hline
\end{tabular}

Developing

Countries

Sub-Sahara

57

Africa

Zimbabwe

Arab States

1.6

Saudi

9.5

57

112

Arabia

Latin

87

152

America/

Caribbean

Mexico

7.9

20.9

84

0.3

10,988

Eastern

Asia/

Oceania

China

Hong Kong

2.5

$23.1^{b}$

$0.6 \quad 141,100$

Southern

Asia

Pakistan

1.9

49

0.9

5580

Least

Developed

Countries

Kiribati

0.80

Developed

Countries

USA

UK

World

${ }^{a}$ World Almanac, $1997{ }^{\mathrm{b}}$ Brittanica Book of the Year, $1997{ }^{\mathrm{c}}$ Billion US\$ (OECD, 1992) ${ }^{d}$ UNESCO, 1996

From a 1988-89 study of the educational use of computers in developing countries, Hawkridge, Jaworski and McMahon (1990) address the critical issue of computer training, especially for teachers, as a major factor on the success or failure of IT in education. They emphasize that training is needed, not only for teachers, but also 
for indigenous teacher trainers, school administrators, revisers of curriculum to integrate computers, software evaluators, specifiers and developers, hardware selectors, and maintainers and policy-makers. Developing countries may seek educational consultants, as resource persons, from developed countries but should be aware that what they propose in hardware, software and training may, or may not, be appropriate for a particular developing country. Input from teachers, students and parents, as important resource people in a developing country, could help insure that what is implemented is appropriate. In addition, a support system needs to be readily available on the use of IT for education.

Professional associations related to IT exist in a number of developing countries and are resources for training, personnel, seminars, conferences, consultations as well as the promotion of IT in education, government, business and in society. A number of international organizations also exist, involving multiple governments, multinational corporations and professional societies in the promotion of IT in education through the exchange of information, and the sharing of expertise, experience, mutual support and cooperation.

UNESCO recently convened, with the cooperation of the Government of the Russian Federation, the Second International Congress on Education and Informatics (EI '96) - Educational Policies and New Technologies - held in Moscow, July 1-5, 1996 (Khvilon and Patru, 1997). At EI '96, declarations and recommendations were adopted by UNESCO, the UN Development Programme, the International Labour Organization (ILO) and the World Bank committing support for the use of IT in education, particularly in developing countries.

In the mid 1980s UNESCO sponsored the Intergovernmental Informatics Programme (Hebentreit, et. al., 1992) in support of training, infrastructure building and national policy development. During the same period, the developed countries cooperated in the use of IT in education through the Commission of the European Community (CEC) and OECD's Centre for Educational Research and Innovation (CERI). A number of collaborative projects between institutions of higher learning that emphasize the use of IT in education has been reported. For example, the Africa Informatics Research Project (Buxton, 1995) involves UNESCO, the African Academy of Science (AAS) and the Association of African Universities in developing the regional cooperation of university informatics research centers and others in solving regional problems.

This paper proposes an association, or 'hierarchy', of countries, regions or schools (in terms of level of IT development only) that might facilitate the sharing of IT educational resources, where the 'development distance' (and perhaps also the 'physical distance' and 'cultural distance') between participants is not great. This is not to suggest that existing relationships between nations nor new linkages between any nations be restricted, but that such a hierarchy could facilitate easier/better understanding and the more appropriate application of IT in education in developing countries. Developed countries could be viewed as resources for developing countries with newly industrializing economies, which could be resources for other developing countries with growing economies, which in turn could be resources for least-developed countries. 
Schools and students in developing and developed countries, or in urban and private schools, with IT experience could be resources for those without, or with less, experience. Higher education institutions, professional associations and businesses could be resources for government, vocational and secondary level schools, which could assist primary schools, and all should be resources for their respective communities. Such a movement has already begun, as evidenced by existing collaborations and associations. Its implementation would involve a large (world) distributed database system with some components likely already in existence. However, it remains for us to identify these components, and to expand and complete the big picture of IT resources around the world and then use them appropriately and respectfully for the good of all.

\section{5}

\section{CONCLUSION}

IT resources for capacity building in developing countries have been presented from available statistics and by the example of the many uses of IT in education around the world. The resources include equipment, software, media, databases, government, people, education, associations and collaborations. The developed and developing countries can work together, as examples have shown, for the good of all, but expanded collaborations hinge on a willingness to cooperate, based on mutual respect, benefit and understanding - all of which rests on the foundation of communication, not just for some, but for all.

Communication, whether by old, traditional means or by new, modern IT must be a two-way, honest, respectful process, which is the foundation of peace. The process must recognize the worth and dignity of both communicating partners - no matter how rich or how poor. There is a richness and a poorness perspective of every nation in a complete view of things. Upon a solid foundation of respectful communication can be built cooperation and trust, out of which comes collaboration, or working together. Collaboration and cooperation are not possible without prerequisite communication. Even in the poorest of countries in the remotest areas, there is a natural hunger for knowledge, 'an abiding faith ... in education as a means of advancing economic and social well-being' (Sagahyroon, 1995). A hierarchy of IT resources, applied respectfully and appropriately, can help to satisfy that hunger and begin to build, at the most fundamental of levels, the capacity of even the poorest of nations to educate and prepare present and future generations, whether rural or urban, for more effective and efficient production and service to society and for a better quality of life for all.

Buxton, T. (1995) Networks \& CD-ROMs aid research, development and education in Zimbabwe. T.H.E. Journal, 22(6), 67-71.

Dedrick, J.L., Goodman, S.E. and Kraemer, K.L. (1995) Little engines that could: computing in small energetic countries. Communications of the $A C M, 38(5)$, 21-26.

Famighetti, R. (ed.) (1996) The World Almanac and Book of Facts 1997. World Almanac Books, K-III Reference Corporation Mahwah, NJ. 
Hawkridge, D., Jaworski, J. and McMahon, H. (1990) Computers in Third-World Schools: Examples, Experience and Issues. St. Martin's Press, New York, NY. Hebenstreit, J., et al. (1992) Education and Informatics Worldwide: The State of the Art and Beyond. Jessica Kingsley Publishers, London, England; UNESCO, Paris, France.

Juliussen, E. and Petska-Juliussen, K. (eds.) (1994) The Computer Industry 199495 Almanac. Computer Industry Almanac, Inc., Dallas, TX.

Katz, R.L. (1988) The Information Society. Praeger Publishers, New York.

Khvilon, E.A. and Patru, M. (1997) UNESCO's mission in the promotion of international cooperation, T.H.E. Journal, 24(6), 58-60.

McHenry, R. (ed.) (1997) 1997 Brittanica Book of the Year. Encyclopaepedia Brittanica, Inc., Chicago, IL.

New Encyclopaedia Brittanica. (1980), Micropaedia, vol. X, 15th Edition, Encyclopaedia Brittanica, Inc., Chicago, IL p. 255.

OECD. (1992) Information Technology Outlook 1992. Organisation for Economic Cooperation and Development, Paris, France.

Sagahyroon, Assim A. (1995) Computer education in developing countries: the Sudan case. Proceedings of the sixth IFIP World Conference on Computers in Education (eds. J.D. Tinsley and T.J. van Weert), Chapman \& Hall, London.

Stover, W. J. (1984) Information Technology in the Third World. Westview Press, Boulder, CO.

Sussman, G. and Lent, J. A. (eds.) (1991) Transnational Communications: Wiring the Third World. Sage Publications, Inc., Newbury Park, CA.

UNESCO, (1997) UNESCO Statistical Yearbook, 1996. United Nations Educational, Scientific and Cultural Organization \& Lanham, MD: Bernan Press Paris, France.

Dr. Marsha R. Williams is a tenured professor of computer science at Tennessee State University, where she teaches and conducts research on Project MISET (Minorities in Science, Engineering \& Technology). She has worked for the University of Mississippi, Memphis State University, IBM and the National Science Foundation. Dr. Williams holds a B.S. degree in physics (Beloit College), M.S. degree in physics (University of Michigan), M.S. and Ph.D. degrees in computer science (Vanderbilt University). She is a Certified Data Processor (CDP) and a member of ACM, AITP (DPMA) and the Tennessee Academy of Science. Her biography appears in Who's Who in the World, Who's Who in Science and Engineering and Who's Who in American Education. 